\title{
ПИСМЕНОСТ ЗА МЕНТАЛНОТО ЗДРАВЈЕ И НАМЕРИ ЗА БАРАЊЕТО ПОМОШ: ИСПИТУВАЊЕ НА ДЕМОГРАФСКИ И ПСИХОЛОШКИ КОРЕЛАТИ
}

\author{
Катерина Наумова ${ }^{1}$

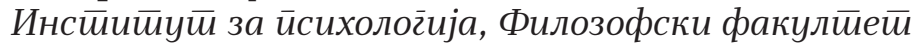

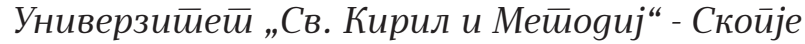

\section{Кратка содржина}

Писменоста за менталното здравје (ПМЗ) е повеќеслоен концепт преку кој се одредуваат знаењата и верувањата за менталните растројства, кои помагаат при нивното препознавање, третман и превенција. Целта на ова истражување е да го испита степенот на ПМЗ во општата популација, неговата поврзаност со намерите за барање професионална помош, како и ефектите на полот, возраста, образованието, психичката вознемиреност, вреднувањето на грижата за сопственото ментално здравје и претходната историја на барање стручна помош. Примерокот се состои од 484 етнички Македонци кои живеат во 15 градови во државата (просечна возраст: 40 години, 51 \% се жени, 43 \% завршиле високо образование). ПМЗ е мерена преку вињети во кои се илустрирани осум ментални растројства: социјална фобија, генерализирано анксиозно растројство, депресија, опсесивно-компулсивно растројство, шизофренија, панично растројство, деменција и биполарно растројство. Со Прашалникой за барање йомош се мерени

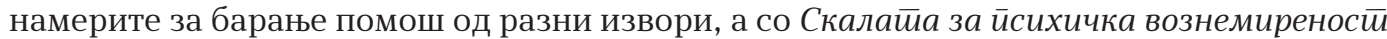
на Кеслер се мерени актуелни симптоми на анксиозност и депресија. Резултатите укажүваат главно на ниски стапки на препознавање на растројствата наспроти повисок степен на знаења за нивниот третман. Стапките на препознавање варираат значајно, при што највисоки се за депресија и деменција, а најниски за биполарно растројство, социјална фобија и генерализирано анксиозно растројство. Спроведените хиерархиски мултипли регресивни анализи потврдија дека женскиот пол и високото образование, како и пониската психичка вознемиреност и претходно добиената стручна помош, предвидуваат повисока ПМЗ, додека значајни предиктори на актуелните намери за барање професионална помош, се само ПМЗ, психичката вознемиреност, претходно добиената стручна помош и вреднувањето на грижата за сопственото ментално здравје. Наодите се дискутирани во контекст на крос-културни споредби, можни импликации и потреба од интервенции за подобрување на ПМЗ.

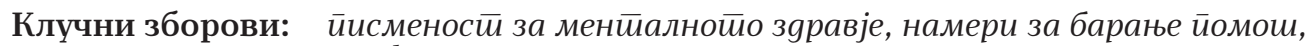
йрофесионална йсихолошка йомош

\footnotetext{
knaumova@fzf.ukim.edu.mk
} 
К. НАУМОВА: ПИСМЕНОСТ ЗА МЕНТАЛНОТО ЗДРАВЈЕ И НАМЕРИ ЗА БАРАњЕТО ПОМОШ...

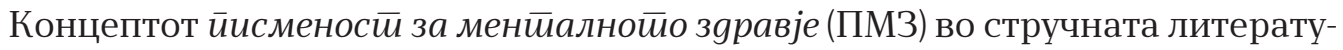
ра за првпат го воведуваат Ентони Џорм и неговите соработници (Jorm et al., 1997), одредувајќи ги на тој начин знаењата и верувањата на една индивидуа (или заедница) за нарушувањата на менталното здравје, кои може да го олеснат процесот на нивно препознавање, пристапување и придржување до третман или превенција.

Овој специфичен вид писменост опфаќа неколку компоненти: а) способност за препознавање на особеностите на поединечни ментални растројства или различни видови психички тешкотии, б) знаења и верувања за факторите на ризик и за причинителите, в) знаења и верувања за стратегиите на самопомош, г) знаења и верувања за професионалната помош, д) ставови кои го поттикнуваат препознавањето и барањето соодветна помош, и ѓ) знаења за барањето информации поврзани со менталното здравје (Jorm, 2000).

Имајќи го предвид високиот процент на ризик во општата популација за директно или индиректно соочување со некаков вид нарушување на менталното здравје (James et al., 2018), согласно перспективата која оваа група автори ја застапуваат, индивидуата што лично или посредно се соочува со симптоми е примарен агенс во процесот на справувањето со нив, додека професионалната помош е една од стратегиите кои притоа може да ги избере. Оттука, повисокиот степен на ПМЗ може да биде извор на зајакнување на ресурсите за поуспешно совладување на психичките тешкотии (Bonabi et al., 2016; Jorm, 2012).

Во двете децении по воведувањето на новиот концепт, неколку прегледни трудови и систематски метаанализи известуваат главно за недоволно висок степен на писменост во општата популација, при што крос-културните споредби покажуваат дека жителите на Западна Европа, Австралија и Северна Америка се поинформирани за менталното здравје, отколку жителите на Азија и Африка (на пример, Angermeyer \& Dietrich, 2006; Furnham \& Hamid, 2014, Jorm, 2012). Крос-културните варијации во лаичките концептуални модели главно се резултат на табуизирањето на менталните растројства во земјите во развој, што повлекува специфични верувања за нивната етиологија и за можностите за третман.

Карактеристично е тоа што, иако наодите се генерализираат на ПМЗ во целост, истражувањата главно се однесуваат на знаења и верувања во однос на неколку ментални растројства, најчесто депресија и шизофренија. Вообичаено, информираноста за особеностите и третманот на депресијата е поголема отколку за шизофренијата, што делумно се објаснува и со значајно повисоката стапка на преваленција на депресијата во различни култури (Furnham \& Hamid, 2014). Меѓутоа, последните неколку години се зголемува интересот и за 
групата анксиозни растројства, каде најниска писменост главно е утврдена за социјалната фобија, додека највисока за опсесивно-компулсивното растројство, иако наодите варираат во зависност од применетата методологија (Furnham \& Lousley, 2013). Спектарот на растројства кон кои се насочува интересот на истражувачите сѐ повеќе се проширува, така што последниве години почесто може да се сретнат и истражувања ориентирани кон повнимателно проучување на писменоста само за едно нарушување (Furnham \& Swami, 2018).

Кога станува збор за социодемографските детерминанти на овој вид писменост и нејзините импликации, утврдени се слични трендови во различни култури. Имено, жените, помладите возрасни и високообразованите покажуваат поголема ПМЗ и подготвеност да побараат професионална помош (Furnham \& Hamid, 2014; Furnham \& Lousley, 2013; Reavley et al., 2014). Дел од авторите ги толкуваат родовите разлики како ефект од зголемената сензитивност на жените кон приливот на релевантни информации за растројства кои се попревалентни кај женскиот род (Furnham \& Lousley, 2013). Други, пак, го издвојуваат конформирањето кон ригидни маскулини норми како бариера за отвореноста на мажите кон препознавање на психичките тешкотии (кај себе и кај другите) и кон барањето соодветна професионална помош (Seidler et al., 2016). Повисокиот степен на образование создава можности за континуиран развој на различни типови писменост, вклучително и на овој, а ефектите од овој процес се поинтензивни до зрелата доба, што делумно објаснува и зошто помладите возрасни, иако не конзистентно, покажуваат поголема способност за правилно препознавање на нарушувањата, но и на соодветните третмани.

Истражувањата кои се фокусирале на барањето помош, откриваат дека повеќето луѓе, кога се соочуваат со психички тешкотии или симптоми на нарушено ментално здравје, избегнуваат да побараат каква било помош. Оние, пак, кои се отворени за помош, почесто се ориентираат кон самопомош или помош од неформални извори (семејство, пријатели), отколку кон професионална помош (Furnham \& Swami, 2018; Oliver et al., 2005).

Оттука, важно е сознанието дека во повеќе наврати се потврдува дека ПМЗ е значаен предиктор на намерата да се бара психолошка помош (Bonabi et al., 2016; Cheng et al., 2016; Rüsch et al., 2011). Друг фактор што може да го олесни овој процес е постоењето претходна историја на контакти со стручњаци за ментално здравје (Cheng et al., 2016; Mackenzie et al., 2006), додека за улогата на актуелното соочување со психички тешкотии има спротивставени наоди - отсуство на поврзаност (O’Connor \& Casey, 2015), наспроти позитивна (Vogel \& Wei, 2005) или негативна поврзаност (Cheng et al., 2016), особено кога интензитетот на симптомите е клинички значаен. Неопходно е да се напоме- 
не дека искуствата од барањето стручна помош, истовремено претставуваат можност и за евентуално зголемување на ПМЗ, исто како што и поголемата рецептивност кон варијациите во актуелното психичко функционирање може да бидат исход од поголема ПМЗ, но и да поттикнат процеси на збогатување на овој вид писменост.

Конечно, возраста е уште еден релевантен фактор за намерата да се побара помош. Емпириските наоди укажуваат дека младите се повеќе ориентирани кон неформални извори, додека повозрасните полесно се одлучуваат за примарна здравствена заштита, отколку за формална психолошка помош (Mackenzie et al., 2006; Oliver et al., 2005; Wilson et al., 2005).

Меѓутоа, литературата за барањето помош се соочува со потреба од концептуална дистинкција меѓу намерите и подготвеноста да се бара помош наспроти манифестираното однесување насочено кон таа цел. Иако повеќето теориски модели постулираат дека намерите, односно подготвеноста (кога се третираат како синоними) се клучни предиктори на идно однесување, емпириските докази не потврдуваат дека исти фактори еднакво успешно ги предвидуваат антецедентите и исходот, што во еден дел може да се должи и на проблематизираната содржинска валидност на применуваните мерки (White et al., 2018).

Општо земено, големиот број обемни истражувања насочени кон ПМЗ во општата популација во т.н. западни и незападни култури, создадоа солидна емпириска основа за постепено пренасочување на истражувачкиот интерес кон поединечни суппопулации и компаративна анализа на писменоста за различни растројства, но и продлабочено разбирање на утврдените сложени односи меѓу знаењата и верувањата за менталното здравје и барањето помош.

Истражувањето, чии наоди се презентирани во овој труд, има две основни цели: 1) да го испита степенот на ПМЗ и истакнатоста на намерата за барање психолошка помош во општата популација, како и нивната заемна поврзаност; 2) да ги испита ефектите на одделни демографски и психолошки корелати во однос на ПМЗ, но и на намерите за барање помош. Се претпоставуваше дека:

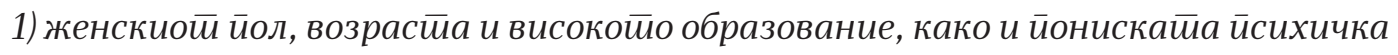

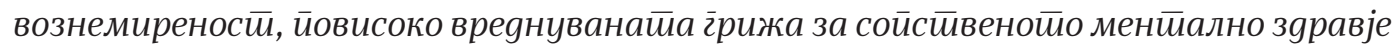

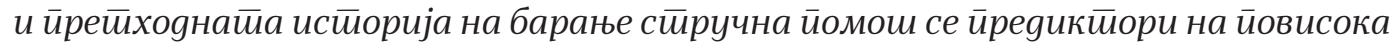
ПМЗ, како и на йоисйакнайа намера за барање йрофесионална йомош; 2) йови-

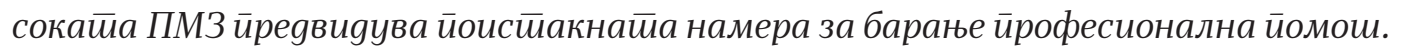

Во литературата се сретнуваат повеќе скали за мерење на ПМЗ (на пример, Compton et al., 2011; Evans-Lacko et al., 2010; O’Connor \& Casey, 2015; Reavley et., 2014). Земајќи предвид дека сите демонстрирале психометриски слабости и ниту една не ги опфаќа сите компоненти на ПМЗ (O’Connor et al., 2014; Wei 
et al., 2015, 2016), а со оглед на тоа што ова е прво истражување на оваа тема во РС Македонија, избран беше почесто користениот метод на вињети, кој покрај потенцијалните ограничувања (Sai \& Furnham, 2013), има и специфични предности (пред сѐ, можноста за давање оригинални одговори).

\section{Метод \\ Исйит̄аници}

Во истражувањето учествуваа 484 испитаници (51 \% од женски пол), етнички Македонци, со место на живеење во петнаесет градови (50 \% од испитаниците живеат во Скопје). Со цел да се обезбеди поголема демографска репрезентативност на примерокот, согласно тековните податоци од Државниот завод за статистика (2018), однапред беше одреден соодносот на процентуална застапеност на испитаниците од двата пола во поединечни возрасни категории, кои живеат во Скопскиот, Централниот, Источниот и Западниот Регион. Испитаниците се на возраст од 18 до 64 години ( $M=$ 39,9 \pm 13,5 години), 57 \% завршиле средно образование, 36 \% високо, а 7 \% се магистри или доктори на науки (испитаници со ниско образование не беа вклучени во примерокот). Според добиените податоци за работниот статус (<1 \% не одговориле на ова прашање), 11 \% од испитаниците се студенти, 15 \% се невработени, 6 \% се пензионери, а 67 \% се вработени (9 \% од нив навеле дека имаат занимање во сферата на здравствената заштита, но не примарно во доменот на менталното здравје, а 10 \% не навеле занимање). Не се утврдени полови разлики во однос на возраста или образованието на испитаниците.

\section{Инструменти}

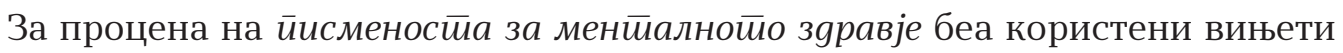
со фиктивни ликови кои се соочуваат со нарушувања на менталното здравје. Испитувана беше информираноста во однос на осум ментални растројства со приспособени вињети преземени од претходни истражувања: социјална фобија (Jorm et al., 2007), генерализирано анксиозно растројство, панично растројство, опсесивно-компулсивно растројство (Coles \& Coleman, 2010), депресија, шизофренија (Jorm et al., 1997), деменција (Рicco et al., 2017) и биполарно растројство (Vargas-Huicochea et al., 2017). Должината на вињетите се движи до 70 до 125 зборови, полот на ликовите во нив наизменично се менува, а опишаните симптоми се во согласност со дијагностичките критериуми во МКБ-10 и ДСМ-4/5. По краткиот опис на нарушувањето, од испитаниците беше побарано: 1) да го именуваат/опишат проблемот со кој лицето се соочува, доколку сметаат дека 
се соочува со проблем; 2) да го именуваат/опишат типот и изворот на професионална помош, доколку сметаат дека таков вид помош е потребна. Одговорите на двете прашања потоа беа засебно кодирани на следниот начин: 0 = не знам/не се соочува со проблем, односно не знам/нема потреба од третман; 1 = препознава проблем, односно потреба од третман, но не може да го именува или наведува проблем, односно третман/извор на помош што не е поврзан со менталното здравје; 2 = наведува проблем поврзан со менталното здравје, односно наведува лекар како извор на помош; 3 = точно идентификувано ментално растројство, односно наведен стручњак за ментално здравје како извор на помош (психолог, психијатар, психотерапевт). На тој начин мерката за ПМЗ може да се третира како бинарна варијабла: точен наспроти неточен одговор или како континуирана варијабла: опсег на вкупен скор 0 - 24 за двете поединечни прашања (информираност за растројствата, $\alpha=.72$, информираност за третманот, $\alpha=.76$ ), односно 0 - 48 за мерката во целост ( $\alpha=.82$ ).

Намерата да се побара помош при соочување со психолошки проблем беше проценета со Прашалникой за барање ӣомош (General Help Seeking Questionnaire, Wilson et al., 2005). Авторите поаѓаат од операционалната дефиниција на намерите како свесен план или одлука да се вложи напор со цел изведување одредено однесување. Со примена на седумстепена скала (1 сигурно не би го сторил/а тоа, 7 - сигурно би го сторил/а тоа), испитаниците ја оценуваа веројатноста дека ќе побараат помош од осум различни извори (формални и неформални) во ситуација кога би се соочиле со личен/емоционален/ психолошки проблем. Листата можеа да ја дополнат со извор што не е наведен, но и да ја изберат опцијата „нема да побарам помош од никого“. Авторите на прашалникот известуваат дека изразените намери при одговарањето значајно се поврзани со манифестираното однесување при барањето помош од блиски или од стручни лица. Со оглед на тоа што при тестирање на хипотезите како критериумска варијабла ќе биде вклучен единствено одговорот за барање помош од стручњак за ментално здравје, коефициентот на внатрешна конзистентност за прашалникот во целост добиен во ова истражување ( $\alpha=.64)$, го наведуваме само како потврда на претходни наоди (Hammer \& Spiker, 2018) дека овој прашалник не е препорачливо да се користи како еднодимензионална мерка.

За процена на актуелната психичка состојба на испитаниците беше користе-

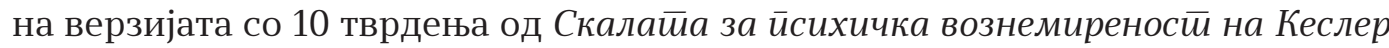
(Kessler Psychological Distress Scale - K10, Kessler et al., 2003). Станува збор за еден од најчесто користените тријажни инструменти за процена на менталното здравје во општа популација. Испитаниците известуваа колку често доживувале симптоми на депресија и анксиозност во изминатиот месец со примена 
на петстепена скала (1 - воопшто не, 5 -речиси постојано). Можниот опсег на скорови е 10 - 50. Утврдена е висока внатрешна конзистентност на скалата во ова истражување ( $\alpha=.87)$. Покрај тоа, конфирматорната факторска анализа ја потврди претпоставената еднофакторска структура на мерката и во овој примерок. При спроведената CFA во пакетот Lavaan R (Rosseel, 2012) со примена на DWLS методот на процена добиени беа следните индекси на согласување (fit) на моделот: $\chi^{2}(35)=52.683, p<.05$, CFI $=.99$, TLI $=.99$, RMSEA $=.03$, SRMR = .06, што дозволува вкупниот скор на скалата да се толкува како индикатор на генерализирана, односно неспецифична психичка вознемиреност.

Покрај социодемографските податоци за полот, возраста, етничката припадност, местото на живеење, работниот статус и занимањето, од испитаниците беше побарано и субјективно да проценат колку им е важна грижата за сопственото ментално здравје (1 -воопшто не ми е важна, 5 - многу ми е важна), како и да дадат податоци дали тие самите, но и нивни блиски (пријател/ роднина/интимен партнер), во текот на животот барале помош од стручњак за ментално здравје (психолог/психотерапевт/психијатар).

\section{Постапка}

Податоците презентирани во овој труд се дел од пообемно истражување спроведено во декември 2018 година и јануари 2019 година. Инструментите ги задаваа студенти по психологија, претходно обучени за овој процес. Сите испитаници дадоа писмена информирана согласност за доброволно учество во истражувањето.

\section{Резултати}

Поради обемноста на добиените дескриптивни податоци за ПМЗ, дел од нив ќе бидат прикажани табеларно (компонентите третирани како бинарни варијабли), а дел само наративно коментирани (поединечните категории одговори за двете компоненти).

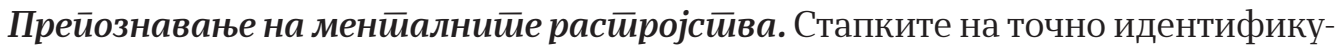
вање на осумте испитувани ментални растројства (табела 1) откриваат генерално низок степен на специфични знаења во однос на оваа клучна компонента на ПМЗ. Дополнително, над четвртина од испитаниците (27 \%) не успеале да препознаат точно ниту едно растројство. Преваленцијата на растројствата се чини дека не е директно поврзана со овој аспект на писменоста, зашто депресијата ја препознале едвај половина од испитаниците, додека социјалната фобија и генерализираното анксиозно растројство (ГАР), помалку од 10 \% (притоа, како 
точни беа кодирани и одговорите социјална анксиозност, односно анксиозност). Покрај тоа, дури 28 \% од испитаниците воопшто не сметале дека ликот опишан во вињетата за ГАР се соочува со каков било проблем.

Табела 1. Стапки на точно препознавање на менталните растројства и на професионалната помош

\begin{tabular}{|c|c|c|}
\hline Растројство & $\begin{array}{c}\text { Правилно } \\
\text { препознавање (\%) }\end{array}$ & $\begin{array}{c}\text { Третман од стручњак за } \\
\text { М3 (\%) }\end{array}$ \\
\hline Социјална фобија ${ }^{\text {a,c }}$ & 5.6 & 71.1 \\
\hline $\begin{array}{l}\text { Генерализирано анксиозно с } \\
\text { растројство }\end{array}$ & 8.1 & 46.1 \\
\hline Депресија с,t† & 48.8 & 57.6 \\
\hline Шизофренија b,c,† & 23.1 & 77.9 \\
\hline Панично растројство а,t† & 24.8 & 36.4 \\
\hline $\begin{array}{l}\text { Опсесивно-компулсивно }{ }^{\mathrm{a}, \mathrm{b}} \\
\text { растројство }\end{array}$ & 31.2 & 595 \\
\hline Деменција b,c,† & 43.2 & 43.2 \\
\hline Биполарно растројство b & 4.8 & 48.6 \\
\hline
\end{tabular}

Забелешка. Растројствата се подредени според редоследот на вињетите. Повисоки стапки на препознавање на растројствата: а жени, b < 40 години, с високообразовани. Повисоки стапки на препознавање на третманот: † жени, †† високообразовани

Со примена на Q-тестот на Кокран се утврди дека варијациите во стапките на точно препознавање на растројствата се статистички значајни $\left(\chi^{2}(7)=633.06\right.$, $p<.001)$. Постхок анализата со тестот на Дан и Бонферони корекцијата покажа дека еднакво се високи стапките за депресија и деменција, додека еднакво се ниски за социјална фобија, биполарно растројство и ГАР. Иако двете анксиозни растројства се опишани во првата и втората вињета, а биполарното растројство во последната, со оглед на варијациите во одговорите за сите растројства (подетално коментирани и подолу), не би можеле да заклучиме дека ефектите од редоследот се главни причини за утврдените ниски стапки. На пример, највисок процент на општа сензитивност за постоење на некаков проблем, кој притоа испитаниците не можеле да го именуваат или го толкувале како одраз на личносни особини, односно одговор на стрес е утврден токму кај социјалната фобија и биполарното растројство (71 \% и 56 \% следствено). Притоа, социјалната фобија ја изедначувале главно со ниска самодоверба, срамежливост, интроверзија, асоцијалност, додека биполарното растројство со исцрпеност, превисока самодоверба, нарцисоидност. За последново нарушување е важно и тоа што секој четврти испитаник (26 \%) не сметал дека ликот во вињетата се соочува со некаков проблем.

Умерена тенденција за генерална сензитивност кон присуството на проблем (33 \% - 45 \%) е утврдена кај другите анксиозни растројства, депресијата 
и шизофренијата. Притоа, испитаниците најчесто го изедначувале опсесивно-компулсивното растројство (ОКР) со прекумерна педантност, а паничното растројство со соматски тегоби.

За деменцијата, пак, е карактеристично тоа што, покрај умерениот процент (табела 1) на точно идентификување на нарушувањето (како деменција или Алцхајмер), уште 38 \% го именувале со користење застарена терминологија (сенилност или склероза), а само < 1 \% сметале дека ликот во вињетата не се соочува со проблем.

Конечно, кога испитаниците демонстрирале препознавање на проблем поврзан со менталното здравје, а не успевале точно да го именуваат, најчесто вниманието го задржувале на еден аспект од опишаното однесување, занемарувајќи ги другите или го толкувале погрешно во целост (на пример, параноја или халуцинации наместо шизофренија, зависност од дрога наместо биполарно растројство, хипохондрија наместо ОКР итн.).

Прейознавање на сооgвейна ӣрофесионална йомош. Втората клучна компонента на ПМЗ се знаењата и верувањата поврзани со професионалната помош. Резултатите покажуваат дека дури и за растројствата кои испитаниците во многу мал процент ги идентификувале точно, препознале потреба од соодветна стручна помош (табела 1), што наведува на заклучок дека овој домен на знаења кај испитаниците е побогат. Дополнително, само 5 \% од нив не предложиле стручна помош за ниту еден опишан проблем.

Тестот на Кокран покажа дека и стапките на точно идентификуван стручен третман за различните растројства значајно варираат $\left(\chi^{2}(7)=384.08, p<.001\right)$, при што постхок анализата откри дека најизразена потреба од соодветна професионална помош испитаниците детектирале кај шизофренијата и социјалната фобија, а најниска кај паничното растројство и деменцијата. Со оглед на тоа што манифестацијата на паничното растројство често ја толкувале како израз на здравствен проблем, повеќе од третина (37 \%) сметале дека соодветен третман може да понудат и матичен лекар и/или лекар специјалист (најчесто интернист). Кај деменцијата, пак, речиси третина (32%) предложиле матичен лекар или лекар (без наведена специјалност) како соодветни извори на помош.

За повисокиот степен на специфични знаења за оваа компонента на ПМЗ, зборува и податокот што во вињетите за анксиозните растројства (освен за OKР) неколкукратно повисока е стапката на посочување психолози како извори на помош (25 \% - 48 \%) наспроти психијатри (5 - 11 \%), додека обратен е соодносот во вињетите за деменција и шизофренија (24 \% и 51 \% наспроти 5 \% и 12 \%). Во сите вињети, мал процент од испитаниците (3 \% - 11 \%) предложиле 
колаборативен третман од страна на психолог и психијатар и/или помош од психотерапевт (3 \% - 6 \%, освен за деменција, каде 11 \% предложиле невролог).

Меѓутоа, наспроти овие наоди, истовремено висок процент испитаници сметале дека ниту ГАР (43 \%) ниту за биполарното растројство (39 \%) воопшто не е потребна каква било професионална помош.

Полови, возрасни и образовни разлики. Во однос на двете компоненти на ПМЗ, споредбените анализи покажаа дека жените подобро од мажите ги препознаваат само анксиозните растројства, освен ГАР (социјална фобија: $\chi^{2}(1)$ $=6.1, p<.05$; панично растројство: $\chi^{2}(1)=14.0, p<.001$; ОКР: $\chi^{2}(1)=4.6, p<.05$ ). Покрај тоа, жените во поголем број од мажите предложиле соодветна професионална помош кај описот на шизофренија $\left(\chi^{2}(1)=5.4, p<.05\right)$ и на деменција $\left(\chi^{2}(1)=6.9, p<.01\right)$.

Испитаниците во рана зрелост (< 40 години) подобро ги препознаваат од повозрасните шизофренијата $\left(\chi^{2}(1)=10.2, p<.01\right)$, ОКР $\left(\chi^{2}(1)=18.5, p<.001\right)$, деменцијата $\left(\chi^{2}(1)=11.3, p<.01\right)$ и биполарното растројство $\left(\chi^{2}(1)=5.1, p<.05\right)$. Меѓутоа, не се подобро информирани од нив за третманот на ниту едно растројство.

Високообразованите подобро од испитаниците со средно образование ги препознаваат социјалната фобија $\left(\chi^{2}(1)=6.0, p<.05\right)$, ГАР $\left(\chi^{2}(1)=8.0, p<.01\right)$, депресијата $\left(\chi^{2}(1)=20.8, p<.001\right)$, шизофренијата $\left(\chi^{2}(1)=7.2, p<.01\right)$ и деменцијата $\left(\chi^{2}(1)=12.7, p<.001\right)$. Подобра информираност од нив за третманот покажале само кај депресијата $\left(\chi^{2}(1)=5.1, p<.05\right)$ и паничното растројство $\left(\chi^{2}(1)=9.5, p<.01\right)$.

Табела 2. Дескриптивни показатели за ПМЗ и за психолошките корелати

\begin{tabular}{lcccccc}
\hline Варијабла & $\boldsymbol{n}$ & $\boldsymbol{M}$ & $\boldsymbol{S D}$ & Опсег & $\boldsymbol{S k}$ & $\boldsymbol{K u}$ \\
\hline ПМЗ вкупен скор & 484 & 28.3 & 9.0 & $3-48$ & -.150 & -.663 \\
Препознавање растројства & 484 & 12.4 & 4.2 & $1-24$ & .209 & -.419 \\
Препознавање третман & 484 & 15.9 & 6.0 & $0-24$ & -.320 & -.953 \\
Психичка вознемиреност (К10) & 474 & 21.5 & 7.0 & $10-47$ & .845 & .607 \\
Грижа за менталното здравје & 465 & 4.5 & 0.8 & $1-5$ & -1.82 & 3.44 \\
Личен контакт со СМ3 & 483 & $21.7 \%$ & - & - & - & - \\
$\begin{array}{l}\text { Блиско лице остварило } \\
\text { контакт со СМ3 }\end{array}$ & 481 & $56.8 \%$ & - & - & - & - \\
\hline
\end{tabular}

Забелешка. СМЗ: стручњак за ментално здравје

Преgвияување на ПМЗ. Увидот во добиените дескриптивни показатели кога ПМЗ се третира како континуирана варијабла (табела 2) ја потврди општата тенденција кај испитаниците подобро да ја препознаваат професионалната помош, отколку самите ментални растројства. Во однос на психичката вознемиреност, во литературата се сретнуваат различни критериумски скорови за толкување на наодите од К10, кои секако не се соодветни за примена кај македонска популација, но во илустративни цели го наведуваме податокот 
дека скорот 20 често се издвојува како долна граница на категоријата лесна психичка вознемиреност. Очигледна тенденција на групирање на податоците кон повисоките скорови е утврдена кај вреднувањето на грижата за сопственото ментално здравје (дури 63 \% од испитаниците изјавиле дека многу им е важна). Најпосле, податоците за претходното однесување поврзано со барањето професионална помош, укажуваат дека секој петти испитаник во својот живот, поради одредени причини, остварил најмалку една средба со стручњак за ментално здравје, додека секој втор навел дека блиско лице, исто така, имало контакти со стручни лица. Полот, возраста и образованието се покажа дека не се значајно поврзани со претпоставените психолошки корелати на ПМЗ.

Табела 3. Предвидување на ПМЗ преку демографски и психолошки корелати

\begin{tabular}{lcccccc}
\hline Варијабли & \multicolumn{3}{c}{ Модел 1 } & \multicolumn{3}{c}{ Модел 2 } \\
\cline { 2 - 7 } & $\mathbf{B}$ & SEB & $\beta$ & B & SEB & $\beta$ \\
\hline Женски пол & 1.88 & .83 & $.10^{*}$ & 1.74 & .81 & $.10^{*}$ \\
Возраст & -.04 & .03 & -.05 & -.04 & .03 & -.06 \\
Високо образование & 3.64 & .83 & $.20^{* * *}$ & 3.20 & .82 & $.18^{* * *}$ \\
Психичка вознемиреност & & & & -.14 & .06 & $-.11^{*}$ \\
$\begin{array}{l}\text { Грижа за } \\
\text { менталното здравје }\end{array}$ & & & & .76 & .53 & .07 \\
Претходна \\
стручна помош
\end{tabular}

${ }^{*} p<.05,{ }^{* * *} p<.001$

Со оглед на тоа што беа задоволени претпоставките за спроведување хиерархиска мултипла регресивна анализа за предвидување на ПМЗ (отсуство на мултиколинеарност, независност, нормална дистрибуција и хомоскедастичност на резидуалите), во првиот блок (табела 3) беа внесени демографските корелати. Моделот е статистички значаен $(F(3,443)=8.57, p<.001)$, но објаснува само 5 \% од варијансата во ПМЗ, при што возраста не е значаен предиктор, додека високото образование има повисок индивидуален придонес од женскиот пол. Кога во вториот блок беа внесени психолошките корелати, предиктивната моќ на моделот се зголеми само за значајни $4 \%(R 2=.09, F(6,440)=8.26, p<.001)$, а во овој случај вреднувањето на грижата за своето ментално здравје не е значаен предиктор. Претходната историја на барање стручна помош има повисок индивидуален придонес од актуелната психичка вознемиреност.

Намери за барање йомош. Прегледот на дескриптивните показатели за намерите да се бара помош од различни извори при соочување со личен, емоционален или психолошки проблем (табела 4), покажува дека кај испитаниците се најизразени намерите да побараат помош од интимниот партнер/ ка (сопруг/сопруга) и од стручњак за ментално здравје, потоа од родител или 
лекар, додека најниска намера е утврдена за барање помош од свештено лице или преку телефонска СОС-линија. Позитивен индикатор е податокот за ниско изразена намера да не се бара помош од никого.

Табела 4. Дескриптивни показатели за намерите за барање помош

\begin{tabular}{|c|c|c|c|c|c|c|}
\hline Извор & $n$ & $M$ & $S D$ & Опсег & $S k$ & $\mathrm{Ku}$ \\
\hline Интимен/на партнер/ка & 476 & 5.7 & 1.9 & $1-7$ & -1.42 & .787 \\
\hline Родител ${ }^{\mathrm{a}, \mathrm{c}}$ & 473 & 5.0 & 2.2 & $1-7$ & -.177 & -1.27 \\
\hline Пријател/ка ${ }^{c}$ & 476 & 4.2 & 2.1 & $1-7$ & -.736 & -.995 \\
\hline Роднина & 476 & 3.7 & 2.1 & $1-7$ & .122 & -1.32 \\
\hline Стручњак за ментално здравје & 476 & 5.6 & 1.8 & $1-7$ & -1.26 & .505 \\
\hline Телефонска СОС линија & 476 & 1.9 & 1.6 & $1-7$ & 2.01 & 3.11 \\
\hline Лекар (општ/специјалист) b,d & 476 & 4.8 & 2.1 & $1-7$ & -.553 & -1.02 \\
\hline Свештено лице & 476 & 2.0 & 1.8 & $1-7$ & 1.68 & 1.48 \\
\hline Нема да барам помош & 476 & 1.6 & 1.4 & $1-7$ & 2.42 & 5.12 \\
\hline
\end{tabular}

Забелешка. Изворите се подредени според редоследот во прашалникот.

Поизразени намери за барање помош: а жени, b средно образование, с пониска возраст, d повисока возраст.

Жените изјавиле дека се посклони од мажите да побараат помош од родителите $(t(471)=-2.05, p<.05)$, додека оние со средно образование полесно би побарале помош од лекар од високообразованите $(t(466)=2.47, p<.05)$. Пониската возраст е поврзана со поизразена намера за барање помош од пријател $(r=-.13, p<.01)$ и родител $(r=-.21, p<.001)$, додека повисоката со поизразена намера да се бара помош од лекар $(r=.11, p<.05)$.

Проверката на предусловите за спроведување хиерархиска мултипла регресивна анализа за предвидување на намерите за барање помош од стручњак за ментално здравје не утврди нормална дистрибуираност и хомоскедастичност на резидуалите, меѓутоа, поради големината на примерокот, овие отстапувања не се од витално значење за конзистентноста и непристрасноста на добиените наоди (Ernst \& Albers, 2017). Во првиот блок (табела 5) беа внесени демографските корелати, но овој модел не беше статистички значаен $(F(3,436)=0.07, p>.05)$. Во вториот блок беа внесени ПМЗ и другите психолошки корелати. Овој модел е статистички значаен $(F(7,432)=11.18, p<.001)$ и објаснува 14 \% од варијансата во намерата да се бара професионална психолошка помош, при што со зголемување на психичката вознемиреност се намалува намерата за барање стручна помош, додека повисоката ПМЗ и вреднувањето на грижата за менталното здравје, како и претходната историја на барање стручна помош, предвидуваат поизразени намери за барање помош од стручњак за ментално здравје. 
Табела 5. Предвидување на намерата за барање професионална помош

\begin{tabular}{lcccccc}
\hline Варијбли & \multicolumn{3}{c}{ Модел 1 } & \multicolumn{3}{c}{ Модел 2 } \\
\cline { 2 - 7 } & В & SEB & $\beta$ & B & SEB & $\beta$ \\
\hline Женски пол & -.06 & .18 & -.02 & -.19 & .16 & -.05 \\
Возраст & .00 & .01 & -.01 & .00 & .01 & .01 \\
Високо образование & -.04 & .18 & -.01 & -.28 & .17 & -.08 \\
Писменост за менталното & & & & .04 & .01 & $.19^{* * *}$ \\
здравје & & & & -.03 & .01 & $-.10^{*}$ \\
Психичка вознемиреност & & & .56 & .11 & $.24^{* * *}$ \\
Грижа за менталното & & & & .62 & .20 & $.14^{* *}$ \\
здравје & & & & & & \\
Претходна стручна помош & & & & & & \\
\hline
\end{tabular}

${ }^{*} p<.05,{ }^{* *} p<.01,{ }^{* * *} p<.001$

Согласно резултатите од спроведените регресивни анализи, може да заклучиме дека првата хипотеза е делумно потврдена, зашто само дел од претпоставените демографски и психолошки корелати успешно ја предвидуваат ПМЗ, додека само психолошките корелати ја предвидуваат намерата за барање професионална помош. Втората хипотеза е потврдена, односно ПМЗ е значаен предиктор на намерата за барање стручна помош во општата популација.

\section{Дискусија}

Испитувањето на писменоста за менталното здравје и намерите за барање помош во општата популација обезбеди повеќе важни сознанија. Пред сѐ, утврдени се значајни варијации во писменоста за одделни ментални растројства, како и во однос на двете клучни компоненти на овој вид писменост: ниска до умерена информираност за растројствата наспроти умерена до висока за професионалната помош. Најпревалентните растројства не се лесно препознатливи за повеќето луѓе. Иако ниски стапки на точно препознавање на анксиозните растројства се утврдени и во други западни култури (Hadjimina \& Furnham, 2017; Furnham \& Lousley, 2013), особено индикативни се наодите за генерализираното анксиозно растројство, каде ниската писменост дополнително се огледува и во истовременото отсуство на сензитивност за препознавање каков било проблем во описот и за потреба од каква било професионална помош. Од друга страна, стапките на точно препознавање на депресија и шизофренија, се речиси еднакви со оние утврдени од Џорм и соработниците, но во првото истражување спроведено во Австралија со примена на истите вињети (Jorm et al., 1997), а пониски се од стапките во неодамнешни истражувања во западни култури, каде се бележи тренд на зголемување на ПМЗ (Furnham \& Swami, 2018; Picco et al., 2017; Sai \& Furnham, 2013). Во споредба, пак, со наоди од Азија и 
К. НАУМОВА: ПИСМЕНОСТ ЗА МЕНТАЛНОТО ЗДРАВЈЕ И НАМЕРИ ЗА БАРАњЕТО ПОМОШ...

Африка, стапките утврдени во ова истражување се главно повисоки (Furnham \& Hamid, 2014).

Биполарното растројство и деменцијата се поретко истражувани, иако интересот за нив од неодамна се зголемува, при што достапните показатели упатуваат на повисоки стапки на точно препознавање во други култури (VargasHuicochea et al., 2017; Vovou et al., 2020; Wickstead \& Furnham, 2017), наспроти оние утврдени во ова истражување, меѓутоа примероците главно биле составени од помлади испитаници.

Крос-културните разлики може да се должат и на варијации во содржините на вињетите како основни стимулуси кои треба да го поттикнат пројавувањето на специфичните знаења и верувања што ја рефлектираат ПМЗ, имајќи предвид дека во некои истражувања паралелната примена на различни описи за исто растројство, кај испитаниците резултирала со значајни варијации во точноста на одговорите (Sai \& Furnham, 2013).

Од друга страна, прашање е дали поставувањето дијагностичка задача пред испитаниците е најдобриот индикатор за нивната писменост, во отсуство на посеопфатен увид во другите компоненти? На пример, стапките на точно препознавање на растројствата во ова истражување се главно ниски, иако кај испитаниците истовремено постои повисок степен на општа сензитивност за идентификување психички или друг вид проблем. Појаснување може да дадат наодите за знаењата и верувањата поврзани со етиологијата на растројствата, кои, иако експлицитно не беа мерени, ги откриваме преку „неточните“ одговори кои испитаниците ги давале при толкувањето на вињетите. Слично како и во други истражувања (Furnham \& Swami, 2018), испитаниците често посредно ги идентификувале личносните особини или психосоцијалните стресори како фактори на ризик или причинители на проблемите, што понатаму упатува дека индивидуата може, барем делумно, да ги регулира појавата и текот на тешкотиите. До одреден степен, тоа можеби ги објаснува и повисоките стапки на посочување стручњаци за ментално здравје како извори на помош, и дистинктивното профилирање на психолошка наспроти психијатриска помош за одделни нарушувања. Крос-културните разлики во системите на здравствена заштита не дозволуваат подетални споредби на овие наоди, меѓутоа, општо земено, и во други западни култури се детектирани повисоки стапки на писменост за третманот наспроти писменоста за растројствата (Furnham \& Lousley, 2013).

Утврдените полови, возрасни и образовни разлики се главно во склад со претходни истражувања (Furnam \& Hamid, 2014; Furnham \& Lousley, 2013; Reavley et al., 2014). Притоа, нивниот ефект е поголем во однос на точното препознавање на растројствата, отколку во однос на информираноста за струч- 
ната помош. За толкување на половите разлики, неопходна е дополнителна проверка со варијации во истражувачкиот нацрт за добивање поконклузивни докази дали станува збор за специфична сензитивност кај жените за поединечни анксиозни растројства и/или за ефект на интеракција меѓу полот на испитаникот/чката и полот на ликот во вињетата (Jorm, 2012). Важен е и наодот што испитаниците во рана зрелост се поинформирани за растројства кои лаичката популација ги опишува како „поневообичаени“ (биполарно растројство, шизофренија, ОКР), што може да биде одраз на барање и/или изложеност на поголем обем информации, особено на социјалните медиуми. Од друга страна, тоа што деменцијата е потешко препознатлива за повозрасните испитаници е загрижувачки наод, зашто утврдената тенденција почесто да ја именуваат со застарена терминологија, упатува на препознавање само на ограничен дел од симптомите карактеристични за оваа категорија невролошки нарушувања, но и нивно толкување како когнитивни или бихевиорални промени кои се неизбежен исход на биолошкото стареење.

Како предиктор на ПМЗ, најголем придонес од демографските варијабли има високото образование. Меѓутоа, иако високообразованите успеваат подобро да ги препознаат најпревалентните, како и други растројства, стапките на препознавање и кај нив не се високи. Оттука, согласно наоди од други култури (Furnham \& Hamid, 2014; Furnham \& Swami, 2018), може да се очекува уште пониска ПМЗ од утврдената во овој примерок, кај популација со ниско образование, но и од рурални средини.

Кога станува збор за барањето помош, утврдени се еднакво високи намери за барање неформална и формална помош кај испитаниците, што не е во согласност со претходни истражувања (Furnham \& Swami, 2018; Oliver et al., 2005). Покрај тоа, не се потврди ниту претпоставката дека демографските варијабли се релевантни фактори за барањето стручна помош, спротивно на претходни истражувања (Furnham \& Hamid, 2014; Furnham \& Swami, 2018), меѓутоа овие разлики може да се должат и на отсуството на дистинкција меѓу намерите, подготвеноста и манифестираното однесување во повеќе истражувања, како и на дефинирањето на профилот на стручњаци релевантни за третманот на менталното здравје, кој се разликува од еден до друг систем на здравствена заштита.

Потврдената поврзаност меѓу минатото однесување насочено кон барањето професионална помош, писменоста за менталното здравје и намерите за идно идентично однесување согласно претходни наоди (Bonabi et al., 2016; Cheng et al., 2016; Rüsch et al., 2011) ја нагласува потребата од проспективни истражувања кои би можеле го појаснат овој веројатно двонасочен однос каде примарно 
повисока ПМЗ може да стимулира барање стручна помош, додека содржината и квалитетот на контактот да поттикнуваат развој на писменоста. Покрај тоа, иако при следни истражувања е пожелно да се направи споредбена анализа меѓу испитаници од т.н. клиничка и неклиничка популација за попрецизен увид во врската меѓу барањето помош, писменоста и психичката вознемиреност, не треба да се занемари наодот дека влошувањето на психичката состојба не е проследено со зголемена информираност за менталното здравје, туку напротив со намален опсег на информации потребни за ефективно препознавање на состојбата, самостојно справување со неа и помалку истакнати намери за барање стручна помош. Фактот што вреднувањето на грижата за сопственото ментално здравје е значаен предиктор на намерите за барање професионална помош, но не е релевантна за ПМЗ, пак, може да укажува на тоа дека оваа глобална самопроцена примарно е одраз на подготвеност за пристапување кон третман при евентуална појава на проблем, но не и кон превенција или посеопфатна ПМЗ.

Наодите за висока подготвеност и намери за барање помош, како и повисока писменост за професионалната помош може да се чинат контрадикторни на реалноста што ја сведочиме и да нѐ наведуваат на заклучок дека веројатно се последица на пристрасност при одговарањето на испитаниците. Меѓутоа, во сложените односи меѓу факторите кои го детерминираат однесувањето при барањето помош неопходно е да не се занемари и улогата на специфичните ставови за овој процес, на субјективно проценетите бариери, како и на објективните општествени или системски пречки, кои не се идентични за одделни суппопулации и/или констелации на психички тешкотии, но кои во голем степен определуваат дали и во кои околности една индивидуа ќе одлучи да побара помош, како и дали потребната помош ќе ѝ биде достапна и ќе одговори соодветно на нејзините потреби (Clement et al., 2015; ten Have et al., 2010).

Очигледно е дека изминативе години сѐ повеќе се зголемува приливот и достапноста на информации за менталното здравје во општата популација, како од формални, така и од неформални извори. Но, истражувањата за квалитетот на информациите достапни на интернет, како основен канал на информирање за голем дел од популацијата, упатуваат на нееднакво висок квалитет на информации за различните нарушувања, како и слабости во однос на читливоста и разбирливоста на текстовите (Grohol et al., 2014). Од друга страна, индивидуалните или групните напори на стручњаците, без соодветна системска поддршка, исто така, често имаат ограничена ефективност. Оттука, земени во целост, резултатите од ова истражување упатуваат на потреба од високо структурирани интервенции за зголемување на ПМЗ како дел од др- 
жавните здравствени политики, кои ќе бидат приспособени на потребите на одделни суппопулации. Од големиот број национални и мултимодални кампањи спроведени во повеќе земји, неколкуте ригорозно евалуирани укажуваат на позитивни исходи, особено кога во фокусот се поединечни нарушувања, а интервенциите се реализирани во контексти, на начини и преку извори соодветни за целната популација (Jorm, 2019). При осмислувањето на овие политики, но и на идните истражувања, неопходно е да се земат предвид и актуелните насоки на развој и проширување на концептот за ПМЗ (Spiker, \& Hammer, 2019), особено сугестиите за поместување на фокусот од менталните растројства кон менталното здравје во целост, како и за реконцептуализирање на конструктот во посеопфатен теориски модел. 


\section{Литература}

Државен завод за статистика на Република Македонија (2018). Рег̄ионийе во Рейублика Макеgонија, 2018 гоgина. http://www.stat.gov.mk/Publikacii/ RegionalenGodisnik2018.pdf

Angermeyer, M. C., \& Dietrich, S. (2006). Public beliefs about and attitudes towards people with mental illness: A review of population studies. Acta Psychiatrica Scandinavica, 113(3), 163-179. https://doi.org/10.1111/j.16000447.2005.00699.x

Bonabi, H., Müller, M., Ajdacic-Gross, V., Eisele, J., Rodgers, S., Seifritz, E., Rössler, W., \& Rüsch, N. (2016). Mental health literacy, attitudes to help seeking, and perceived need as predictors of mental health service use: A longitudinal study. The Journal of Nervous and Mental Disease, 204(4), 321-324. https://doi.org/10.1097/NMD.0000000000000488

Cheng, H.-L., Wang, C., McDermott, R. C., Kridel, M., \& Rislin, J. L. (2018). Selfstigma, mental health literacy, and attitudes toward seeking psychological help. Journal of Counseling \& Development, 96(1), 64-74. https://doi. org/10.1002/jcad.12178

Clement, S., Schauman, O., Graham, T., Maggioni, F., Evans-Lacko, S., Bezborodovs, N., Morgan, C., Rüsch, N., Brown, J. S. L., \& Thornicroft, G. (2015). What is the impact of mental health-related stigma on help-seeking? A systematic review of quantitative and qualitative studies. Psychological Medicine, 45(1), 11-27. https://doi.org/10.1017/ S0033291714000129

Coles, M. E., \& Coleman, S. L. (2010). Barriers to treatment seeking for anxiety disorders: Initial data on the role of mental health literacy. Depression and Anxiety, 27(1), 63-71. https://doi.org/10.1002/da.20620

Compton, M. T., Hankerson-Dyson, D., \& Broussard, B. (2011). Development, item analysis, and initial reliability and validity of a multiple-choice knowledge of mental illnesses test for lay samples. Psychiatry Research, 189(1), 141148. https://doi.org/10.1016/j.psychres.2011.05.041

Ernst, A.F, \& Albers, C.J. (2017). Regression assumptions in clinical psychology research practice-a systematic review of common misconceptions. PeerJ 5:e3323 https://doi.org/10.7717/peerj.3323

Evans-Lacko, S., Little, K., Meltzer, H., Rose, D., Rhydderch, D., Henderson, C., \& Thornicroft, G. (2010). Development and psychometric properties of the Mental Health Knowledge Schedule. The Canadian Journal of Psychiatry, 55(7), 440-448. https://doi.org/10.1177/070674371005500707 
Furnham, A., \& Hamid, A. (2014). Mental health literacy in non-western countries: A review of the recent literature. Mental Health Review Journal, 19(2), 84-98. https://doi.org/10.1108/MHRJ-01-2013-0004

Furnham, A., \& Lousley, C. (2013). Mental health literacy and the anxiety disorders. Health, 05(03), 521-531. https://doi.org/10.4236/ health.2013.53A071

Furnham, A., \& Swami, V. (2018). Mental health literacy: A review of what it is and why it matters. International Perspectives in Psychology: Research, Practice, Consultation, 7(4), 240-257. https://doi.org/10.1037/ipp0000094

Grohol, J. M., Slimowicz, J., \& Granda, R. (2014). The quality of mental health information commonly searched for on the Internet. Cyberpsychology, Behavior, and Social Networking, 17(4), 216-221. https://doi.org/10.1089/ cyber.2013.0258

Hadjimina, E., \& Furnham, A. (2017). Influence of age and gender on mental health literacy of anxiety disorders. Psychiatry research, 251, 8-13. https:// doi.org/10.1016/j.psychres.2017.01.089

Hammer, J. H., \& Spiker, D. A. (2018). Dimensionality, reliability, and predictive evidence of validity for three help-seeking intention instruments: ISCI, GHSQ, and MHSIS. Journal of Counseling Psychology, 65(3), 394-401. https:// doi.org/10.1037/cou0000256

James, S. L., Abate, D., Abate, K. H., Abay, S. M., Abbafati, C., Abbasi, N., Abbastabar, H., Abd-Allah, F., Abdela, J., Abdelalim, A., Abdollahpour, I., Abdulkader, R. S., Abebe, Z., Abera, S. F., Abil, O. Z., Abraha, H. N., AbuRaddad, L. J., Abu-Rmeileh, N. M. E., Accrombessi, M. M. K., ... Murray, C. J. L. (2018). Global, regional, and national incidence, prevalence, and years lived with disability for 354 diseases and injuries for 195 countries and territories, 1990-2017: A systematic analysis for the Global Burden of Disease Study 2017. The Lancet, 392(10159), 1789-1858. https://doi. org/10.1016/S0140-6736(18)32279-7

Jorm, A. F. (2000). Mental health literacy: Public knowledge and beliefs about mental disorders. British Journal of Psychiatry, 177(5), 396-401. https://doi. org/10.1192/bjp.177.5.396

Jorm, A. F. (2012). Mental health literacy: Empowering the community to take action for better mental health. American Psychologist, 67(3), 231-243. https://doi.org/10.1037/a0025957

Jorm, A. F. (2019). Mental health literacy interventions in adults. In O. Okan, U. Bauer, P. Pinheiro, D. Zamir-Levin, \& K. Sørensen (Eds.) International handbook of health literacy: Research, practice and policy across the lifespan (1st ed., pp.359-370). Policy Press. 
Jorm, A. F., Korten, A. E., Jacomb, P. A., Christensen, H., Rodgers, B., \& Pollitt, P. (1997). "Mental health literacy": A survey of the public's ability to recognise mental disorders and their beliefs about the effectiveness of treatment. Medical Journal of Australia, 166(4), 182-186. https://doi. org/10.5694/j.1326-5377.1997.tb140071.x

Jorm, A. F., Wright, A., \& Morgan, A. J. (2007). Beliefs about appropriate first aid for young people with mental disorders: Findings from an Australian national survey of youth and parents. Early intervention in psychiatry, 1(1), 61-70. https://doi.org/10.1111/j.1751-7893.2007.00012.x

Kessler, R. C., Barker, P. R., Colpe, L. J., Epstein, J. F., Gfroerer, J. C., Hiripi, E., Howes, M. J., Normand, S.-L. T., Manderscheid, R. W., Walters, E. E., \& Zaslavsky, A. M. (2003). Screening for serious mental illness in the general population. Archives of General Psychiatry, 60(2), 184. https://doi. org/10.1001/archpsyc.60.2.184

Mackenzie, C. S., Gekoski, W. L., \& Knox, V. J. (2006). Age, gender, and the underutilization of mental health services: The influence of helpseeking attitudes. Aging \& Mental Health, 10(6), 574-582. https://doi. org/10.1080/13607860600641200

O'Connor, M., \& Casey, L. (2015). The Mental Health Literacy Scale (MHLS): A new scale-based measure of mental health literacy. Psychiatry Research, 229(1-2), 511-516. https://doi.org/10.1016/j.psychres.2015.05.064

O'Connor, M., Casey, L., \& Clough, B. (2014). Measuring mental health literacy a review of scale-based measures. Journal of Mental Health, 23(4), 197-204. https://doi.org/10.3109/09638237.2014.910646

Oliver, M., Pearson, N., Coe, N., \& Gunnell, D. (2005). Help-seeking behaviour in men and women with common mental health problems: Cross-sectional study. British Journal of Psychiatry, 186(4), 297-301. https://doi:10.1192/ bjp.186.4.297

Picco, L., Seow, E., Chua, B. Y., Mahendran, R., Verma, S., Chong, S. A., \& Subramaniam, M. (2017). Recognition of mental disorders: Findings from a cross-sectional study among medical students in Singapore. BMJ Open, 7(12), e019038. https://doi.org/10.1136/bmjopen-2017-019038

Reavley, N. J., Morgan, A. J., \& Jorm, A. F. (2014). Development of scales to assess mental health literacy relating to recognition of and interventions for depression, anxiety disorders and schizophrenia/psychosis. Australian \& New Zealand Journal of Psychiatry, 48(1), 61-69. https://doi. org/10.1177/0004867413491157

Rosseel, Y. (2012). lavaan: An R Package for Structural Equation Modeling. Journal of Statistical Software, 48, 1-36. https://doi.org/10.18637/jss.v048.i02 
Rüsch, N., Evans-Lacko, S. E., Henderson, C., Flach, C., \& Thornicroft, G. (2011). Knowledge and attitudes as predictors of intentions to seek help for and disclose a mental illness. Psychiatric Services, 62(6), 675-678. https://doi. org/10.1176/ps.62.6.pss6206_0675

Sai, G., \& Furnham, A. (2013). Identifying depression and schizophrenia using vignettes: A methodological note. Psychiatry Research, 210(1), 357-362. https://doi.org/10.1016/j.psychres.2013.05.004

Seidler, Z. E., Dawes, A. J., Rice, S. M., Oliffe, J. L., \& Dhillon, H. M. (2016). The role of masculinity in men's help-seeking for depression: A systematic review. Clinical Psychology Review, 49, 106-118. https://doi.org/10.1016/j. cpr.2016.09.002

Spiker, D. A., \& Hammer, J. H. (2019). Mental health literacy as theory: Current challenges and future directions. Journal of Mental Health, 28(3), 238-242. https://doi.org/10.1080/09638237.2018.1437613

ten Have, M., de Graaf, R., Ormel, J., Vilagut, G., Kovess, V., \& Alonso, J. the ESEMeD/MHEDEA 2000 Investigators (2010). Are attitudes towards mental health help-seeking associated with service use? Results from the European Study of Epidemiology of Mental Disorders. Social Psychiatry and Psychiatric Epidemiology, 45(2), 153-163. https://doi.org/10.1007/s00127009-0050-4

Vargas-Huicochea, I., Robles-García, R., Berlanga, C., Tovilla-Zárate, C. A., Martínez-López, N., Fresán, A. (2017). Mental health literacy about bipolar disorder and schizophrenia among medical students: A comparative study of illness recognition, treatment, and attitudes according to perception of aggressiveness-dangerousness. Salud mental, 40(4), 141-148. https://doi. org/10.17711/SM.0185-3325.2017.018

Vogel, D. L., \& Wei, M. (2005). Adult attachment and help-seeking intent: The mediating roles of psychological distress and perceived social support. Journal of Counseling Psychology, 52(3), 347-357. https://doi. org/10.1037/0022-0167.52.3.347

Vovou, F., Hull, L., \& Petrides, K. V. (2020). Mental health literacy of ADHD, autism, schizophrenia, and bipolar disorder: A cross-cultural investigation. Journal of Mental Health, 1-11. https://doi.org/10.1080/096382 37.2020.1713999

Wei, Y., McGrath, P. J., Hayden, J., \& Kutcher, S. (2015). Mental health literacy measures evaluating knowledge, attitudes and help-seeking: A scoping review. BMC Psychiatry, 15(1), 291. https://doi.org/10.1186/s12888-015-0681-9

Wei, Y., McGrath, P. J., Hayden, J., \& Kutcher, S. (2016). Measurement properties of tools measuring mental health knowledge: A systematic review. BMC Psychiatry, 16(1), 297. https://doi.org/10.1186/s12888-016-1012-5 
White, M. M., Clough, B. A., \& Casey, L. M. (2018). What do help-seeking measures assess? Building a conceptualization framework for helpseeking intentions through a systematic review of measure content. Clinical Psychology Review, 59, 61-77. doi:10.1016/j.cpr.2017.11.001

Wickstead, R., \& Furnham, A. (2017). Comparing mental health literacy and physical health literacy: An exploratory study. Journal of Mental Health, 26(5), 449-456. https://doi.org/10.1080/09638237.2017.1294743

Wilson, C., Deane, F., Ciarrochi, J., \& Rickwood, D. (2005). Measuring helpseeking intentions: Properties of the General Help-Seeking Questionnaire. Canadian Journal of Counselling, 39, 15-28. 
MENTAL HEALTH LITERACY AND HELP-SEEKING INTENTIONS: EXAMINING DEMOGRAPHIC AND PSYCHOLOGICAL CORRELATES

\author{
Katerina Naumova
}

\begin{abstract}
Mental health literacy (MHL) is a multifaceted concept referring to knowledge and beliefs about mental disorders which aid their recognition, treatment or prevention. The aim of this study is to investigate the level of MHL in the community, its relation to professional help-seeking intentions and the effects of gender, age, education, psychological distress, self-rated importance of personal mental health care and prior help-seeking. The sample consists of 484 ethnic Macedonians (average age: 40 years, 51\% female, 43\% have a university degree) living in 15 cities in the country. MHL was measured using vignettes illustrating eight mental disorders: social phobia, general anxiety disorder, depression, obsessive-compulsive disorder, schizophrenia, panic disorder, dementia and bipolar disorder. The General Help Seeking Questionnaire was used for measuring help-seeking intentions from various sources, and Kessler Psychological Distress Scale (K10) was used for measuring anxiety and depression. Participants mainly showed low recognition of mental disorders opposed to a higher level of knowledge on treatment. Recognition rates varied significantly across disorders (highest for depression and dementia, lowest for bipolar disorder, social phobia and general anxiety disorder). The hierarchical multiple regression analyses revealed that female gender and university education are significant predictors of MHL, as well as lower psychological distress and prior professional help-seeking. With respect to professional help-seeking intentions, MHL, prior professional help-seeking, psychological distress and self-rated importance of personal mental health care are significant predictors. Findings are discussed in terms of cross-cultural comparisons, potential implications and the need for MHL interventions.
\end{abstract}

Keywords: mental health literacy, help-seeking intentions, professional psychological help 